Boston University School of Law Scholarly Commons at Boston University School of Law

Faculty Scholarship

2008

\title{
Should Access to Medicines and TRIPS Flexibilities Be Limited to Specific Diseases?
}

Kevin Outterson

Boston Univeristy School of Law

Follow this and additional works at: https://scholarship.law.bu.edu/faculty_scholarship

Part of the Intellectual Property Law Commons

\section{Recommended Citation}

Kevin Outterson, Should Access to Medicines and TRIPS Flexibilities Be Limited to Specific Diseases?, 34 American Journal of Law and Medicine 279 (2008).

Available at: https://scholarship.law.bu.edu/faculty_scholarship/567 


\title{
Should Access to Medicines And TRIPS Flexibilities Be Limited To Specific Diseases?
}

\author{
Kevin Outterson ${ }^{\dagger}$
}

\section{DISEASE-BASED LIMITATIONS IN GLOBAL PATENT LAW}

The health needs of most of the world's population are not well served by patent-based pharmaceutical markets. The poor in low- and medium-income countries (LMICs) lack the financial resources to sustain the attention of global commercial drug companies. After an extensive consultation process, in 2006, the World Health Organization's Commission on Innovation, Intellectual Property and Public Health issued its Report (the WHO CIPIH REPORT), finding this concern to be significant:

In the context of our work one of the important points is that, where the market has very limited purchasing power, as is the case for diseases affecting millions of poor people in developing countries, patents are not a relevant factor or effective in stimulating R\&D and bringing new products to market. ${ }^{1}$

On this issue, the WHO CIPIH Report was preceded by the Access to Medicines movement, an informal coalition of civil society organizations such as Médecins Sans Frontières, Treatment Action Campaign, Health GAP, Oxfam, and Knowledge Ecology International (formerly the Consumer Project on Technology). These groups and many others identified patents on pharmaceuticals as an inappropriate barrier to access in developing countries. $^{2} \quad$ They devoted particular attention to the World Trade

Associate Professor, Boston University School of Law. Editor's Note: This symposium was held at Boston University in February 2008. In May 2008, the 61st World Health Assembly met in Geneva and adopted a Global Health Strategy on Public Health, Innovation and Intellectual Property, following the final meeting of the Inter-Govermental Working Group (IGWG 2) on May 3, 2008. This paper was circulated in draft form at IGWG 2, but has not been modified to account for the final resolution. In general, the WHA final resolution is supportive of the approach taken in this article, due to the efforts of many delegations and observers.

1 World Health Organization, Report of the Commission on Intellectual Property Rights, Innovation and Public Health 22 (2006) [hereinafter WhO CiPiH REPORT].

${ }_{2}$ See, e.g., Médecins Sans Frontières, A Guide to the Post-2005 World: TRIPS, R\&D AND Access to Medicines (2005), www.msf.org/msfinternational/invoke.cfm?compone 
Organization TRIPS Agreement, which is the minimum global legal standard for pharmaceutical patents. ${ }^{3}$ In response to challenges about the need for innovation, some have reframed the movement as "Access + Innovation." This article follows in the Access + Innovation genre, attempting to simultaneously address both equitable access and optimal innovation. ${ }^{4}$

Global patent-based pharmaceutical companies and the United States Trade Representative (USTR) have not been particularly supportive of the Access + Innovation agenda. ${ }^{5}$ Many attempts have been resisted, even to the point of suing South Africa for its use of unlicensed AIDS drugs in the face of an epidemic. ${ }^{6}$ In response to sustained global pressure, the companies eventually conceded the case in South Africa, and the WTO members unanimously adopted the Doha Declaration in November 2001. However, several attempts have been made to limit access initiatives and TRIPS flexibilities to particular diseases, namely AIDS, tuberculosis and malaria, or more generally to infectious public health emergencies. ${ }^{7}$

The primary concern appears to be profit-driven: companies are concerned that any flexibilities for LMICs could lead to price erosion in highincome markets, through physical or virtual arbitrage, ${ }^{8}$ demands for expanded access, compulsory licensing, or other TRIPS flexibilities. ${ }^{9}$ These concerns are especially acute for blockbuster drugs treating major chronic diseases.

nt=article\&objectid=88694E5B-OFED-434A-A21EDA1006002653\&method=full_html.

${ }_{3}$ See Agreement on Trade-Related Aspects of Intellectual Property Rights, Annex 1C art. 8(1), Apr. 15, 1994,3 3 I.L.M. 81, available at www.wto.org/english/docs e/legal e/27trips.pdf (Marrakesh Agreement Establishing the World Trade Organization) [hereinafter TRIPS or TRIPS Agreement].

${ }_{4}$ For a longer treatment on this balance, see Kevin Outterson, Pharmaceutical Arbitrage: Balancing Access and Innovation in International Prescription Drug Markets, 5 Yale J. Health Pol'y, L. \& Ethics 193-286 (2005), available at www.ssrn.com/abstract=567742 [hereinafter Pharmaceutical Arbitrage].

5 See e.g., Michael P. Ryan, Knowledge Diplomacy: Global Competition and the Politics of Intellectual Property (Brookings Institution Press 1998); Duncan Matthews, Globalizing Intellectual Property Rights (Richard Higgott ed., Routledge 2002); Peter Drahos with John Braithwaite, Information Feudalism: Who Owns the Knowledge Economy? (The New Press 2002); Susan K. Sell, Power and Ideas: NorthSouth Politics of Intellectual Property and Antitrust (James N. Rosenau, ed., State University of New York Press 1998); Susan K. Sell, Private Power, Public law: The Globalization of Intellectual Property Rights (Steve Smith, ed., Cambridge University Press 2003); Laurence R. Helfer, Regime Shifting: The TRIPS Agreement and New Dynamics of International Intellectual Property Lawmaking, 29 YALE J. InT'L L. 1 (2004). For a report that ranks pharmaceutical companies based upon their commitment to access initiatives, see Access to Medicine Index, www.atmindex.org (last visited Mar. 24, 2008).

6 WHO CIPIH REPORT, supra note 1, at 121.

7 See infra Section III; see also U.S. Gen. Accounting Office, GAO Report 07-1198, U.S. Trade Policy Guidance on WTO Declaration on Access to Medicines May Need Clarification 15, 19, 23 (Sept. 2007) [hereinafter, GAO Trade Policy Report].

8 Pharmaceutical Arbitrage, supra note 4, at 193-286; Outterson \& Kesselheim, Market-Based Licensing for HPV Vaccines in Developing Countries, 27 Health AfF. 131, 131 (2008); GAO Trade Policy Report, supra note 7, at 24; WHO CIPIH Report, supra note 1, at 111-12. For a recent example of the conventional view, see Patricia M. Danzon, At What Price?, 449 NATURe 176 (2007).

9 Many LMICs have not taken advantage of the flexibilities permitted under TRIPS. William New, Disparities Seen In Developing Countries' TRIPS Implementation (Dec. 11, 2007), available at www.ip-watch.org/weblog/index.php?p=865. TRIPS permitted many developing countries to implement its provisions on a delayed basis. TRIPS Agreement, supra note 3, at arts. 65-66. After extensions, most developing countries must have 
Nothing in the TRIPS Agreement limits compulsory licenses or other flexibilities to a narrow category of diseases. In the Doha Declaration itself, the U.S. requested an explicit limitation to particular diseases, and was the last country to assent to the unanimous resolution. ${ }^{10}$ The ultimate compromise language states:

We recognize the gravity of the public health problems afflicting many developing and least-developed countries, especially those resulting from HIV/AIDS, tuberculosis, malaria and other epidemics. ${ }^{11}$

At first blush, this appears to be a disease-specific limitation, but the Doha Declaration merely uses the Big 3 to illustrate examples of "national emergency or other circumstances of extreme urgency." 12 The Doha Declaration clearly supports WTO Members' rights to utilize TRIPS flexibilities - including compulsory licensure and parallel trade - to "protect public health" without regard to the type of disease: ${ }^{13}$

Accordingly, while reiterating our commitment to the TRIPS Agreement, we affirm that the Agreement can and should be interpreted and implemented in a manner supportive of WTO Members' right to protect public health and, in particular, to promote access to medicines for all. ${ }^{14}$

This point has been honored primarily in the breach. Under the Doha Declaration "Paragraph 6" process, compulsory licenses could be issued for export to low-income countries, bypassing Article 31(f) of the TRIPS Agreement, which restricts compulsory licenses predominantly for domestic use. When Canada enacted its Access to Medicines Regime to permit Paragraph 6 exports, the law limited compulsory licenses to specific listed

implemented the TRIPS Agreement by January 1, 2005, but the thirty "least developed countries" may defer full implementation for pharmaceutical products until 2016. World Trade Organization, Doha Ministerial Declaration on the TRIPS Agreement and Public Health of 20 Nov. 2001, WT/MIN(01)/DEC/2, ๆ 7 (2001) [hereinafter Doha Declaration]. Despite these concessions, all but three of Africa's Least Developed Countries (LDCs) have already adopted patent laws for pharmaceuticals. Phil Thorpe, Study on the Implementation of the TRIPS Agreement by Developing Countries 1 (Comm. on Intellectual Prop. Rights, Study Paper 7) (2004). Similarly, Latin America has not fully availed itself of TRIPS flexibilities, with varying levels of sensitivity between countries. Gabriela Costa Chaves and Maria Auxiliadora Oliveira, A Proposal For Measuring The Degree of Public Health-Sensitivity of Patent Legislation In The Context of the WTO TRIPS Agreement, 85 Bull. World Health OrG. (Jan. 2007). The TRIPS Agreement merely sets minimum periods of IP protection; the United States can still unilaterally extend patent protection, and has done so with copyright. WTO Members are also free to negotiate so-called "TRIPS-plus" agreements with additional provisions requiring protections in excess of the TRIPS Agreement's minimum standards. The U.S. has done so with a number of bilateral and multilateral treaties. Médecins SANs Frontières, MSF Briefing note, Access to Medicines at Risk Across the Globe: What To Watch Out For in Free Trade Agreements with the United States 4-6 (2004). For an explanation of why most developing country patent offices have not taken full advantage of TRIPS flexibilities, see Peter Drahos, "Trust Me": Patent Offices in Developing Countries, 34 AM. J.L. \& MED. (2008).

10 GAO Trade Policy Report, supra note 7, at 23.

${ }^{11} \quad$ Doha Declaration, supra note 9, at par. 1.

$12 \quad$ Id. at par. 5(c).

13 Id. at par. 4, 5(b), 5(c), 5(d); GAO Trade Policy Report, supra note 7, at 11-26.

14. Doha Declaration, supra note 9, at par. 4. 
medicines. ${ }^{15}$ This list has been criticized for its excessive narrowness - only 57 drugs or vaccines. ${ }^{16}$ The list is effectively limited to AIDS and off-patent medications. Many of the listed drugs treat AIDS; and most of those AIDS drugs are available generically already. Almost all of the other drugs on the list are off-patent or face legal generic competition in a similar form. ${ }^{17}$ The only patented non-AIDS drugs on the list are eflornithine (for the treatment of African sleeping sickness) and levofloxacin (an important antibiotic). Others are just curious choices considering the global burden of disease (testosterone injection). Ivermectin is also listed, despite Merck's promise to donate it in the river blindness campaign. The very narrow positive list in the Canadian Access to Medicines Regime operates as a disease-specific limitation on compulsory licensure under Paragraph 6 .

More recently, major drug companies and USTR have resisted Thailand's efforts to issue compulsory licenses on patented drugs for heart disease and cancer. ${ }^{18}$ When Thailand attempted to use the very TRIPS flexibilities guaranteed and encouraged by the Doha Declaration, a backlash ensued from conservative media, pharmaceutical manufacturers, and the U.S. government. The Wall Street Journal editorial page attacked the Thai compulsory licenses as "seizures" that cynically distorted WTO rules, while a propertyrights activist group charged the Thai government with violating global trade rules. $^{19}$ Abbott, the manufacturer of lopinavir/ritonavir, withdrew pending applications for drugs in Thailand, including a heat-stable version of an important fixed-dose combination drug for AIDS with particular usefulness in a tropical climate. ${ }^{20}$ The USTR then placed Thailand on the special 301 "priority watch list" for alleged violations of intellectual property law, mentioning in particular the compulsory license. ${ }^{21}$

15 The Jean Chretien Pledge to Africa Act, 2004 S.C., ch. 23 (Can.), available at www.canlii.org/ca/as/2004/c23/part2620\%2Ehtml [hereinafter CANADIAN Access to Medicines Regime or CAMR]. The law created a positive list of drugs eligible for compulsory licensure, a procedural hurdle not required by the WTO. Id at Sched. 1.

16 Jillian C. Cohen-Kohler et al., Canada's Implementation of the Paragraph 6 Decision: Is It Sustainable Public Policy?, 3 Globalization \& Health (2007), available at www.globalizationandhealth.com/content/3/1/12.

${ }_{17}$ The off-patent drugs include: amphotericin B, azithromycin, beclomethasone/beclometasone, ceftazidime, ceftriaxone, ciclosporin(e), ciprofloxacin, daunorubicin, doxorubicin, enalapril, erythromycin, etoposide, ibuprofen, isoniazid + pyrazinamide, insulin, ivermectin, levodopa + carbidopa, lithium carbonate, metoclopramide, metronidazole, morphine, nifedipine, nitrofurantoin, ofloxacin, potassium chloride, rifampin, salbutamol/albuterol, timolol. Patent status was taken from the U.S. FDA Orange Book. See Electronic Orange Book, Approved Drug Products with Therapeutic Equivalents, www.fda.gov/cder/ob/default.htm (last visited Mar. 24, 2008).

18 Apiradee Treerutkuarkul, Talks With Pharma-Giants Collapse, Bangkoк Post, Dec. 18, 2007; Brent Savoie, Thailand's Test: Compulsory Licensing In An Era of Epidemiologic Transition, 48 VA. J. INT'L L. 211 (2007); Outterson \& Kesselheim, supra note 8, at 133.

19 Editorial, Bangkok's Drug War Goes Global, Wall Street Journal, Mar. 7, 2007; M. Vaughan, In Clash with Activists, Critics Charge Thailand Violation of Trade Rules, Intell. Prop. Watch, Mar. 19, 2007.

${ }_{20}$ Press Release, Médecins Sans Frontières, Abbott Should Reconsider its Unacceptable Decision to Not Sell New Medicines in Thailand (March 23, 2007), available at www.worldaidscampaign.info/index.php/en/campaigns/in_country_campaigns/asia/abbott_s hould_reconsider_its_unacceptable_decision_to_not_sell_new_medicines_in_thailand.

21 Office of the U.S. Trade Representative, 2007 Special 301 Report 27 (2007) [hereinafter,SPECIAL 301 REPORT]. 
The TRIPS Agreement is subject to dispute resolution under the WTO Dispute Settlement Understanding, but the U.S. Government is unlikely to initiate a WTO panel against Thailand. The TRIPS Agreement authorizes members like Thailand to issue compulsory licenses for these drugs. ${ }^{22}$ For all the bluster in the Wall Street Journal, it is clear that the controlling legal texts do not limit the use of TRIPS flexibilities to any particular set of diseases.

Nor should they. From the perspective of public health, limiting access programs and TRIPS flexibilities to particular diseases would be quite dangerous and unnecessary. Dangerous because the diseases of the world's rich and poor countries are converging, including non-communicative diseases such as heart disease, stroke, diabetes, cancer and depression. Radically cheaper medicines for these conditions could significantly improve health in LMICs. Limitation is also unnecessary because proven tools can be deployed to preserve high-income markets while LMICs pursue equitable flexibilities. ${ }^{23}$

Perhaps another factor is at work here as well. An implicit assumption is that the diseases of developing countries are essentially different from diseases in the United States or Europe. Paradigmatic cases include exotic tropical diseases such as ebola hemorrhagic fever ${ }^{24}$ and onchocerciasis (river blindness). These neglected diseases and their victims are so remote from the U.S. experience that special charitable programs seem unobjectionable. Only a very small portion of the disease burden in developing countries comes from these exotic tropical neglected diseases. ${ }^{25}$ Drugs produced for high-income markets can treat most of the global disease burden, such as the pressing need for cancer therapies in LMICs, where cancer deaths outnumber AIDS deaths. ${ }^{26}$ The number one cause of death in LMICs is not a neglected tropical disease, but a familiar "rich country" killer: heart disease. ${ }^{27}$

To date, the important global legal texts retain broad application to all relevant diseases, but some parties continue to propose disease-specific limitations, most recently in the World Health Organization's Intergovernmental Working Group on Public Health, Innovation and

22 Indeed, as the GAO reports, the USTR itself concedes the point. See GAO Trade Policy REPORT, supra note 7, at 48-49. The USTR stated that the decision to place Thailand on the Special 301 "priority watch list" was based "not solely on [Thailand's] compulsory license decision." Id. at 49.

23 For my most recent defense of equitable access in the face of diversion, see generally Outterson \& Kesselheim, supra note 8. For an earlier defense set in a broader theoretical context, see Pharmaceutical Arbitrage, supra note 4, at 261-68. In the context of adaptive innovation leading to the creation of a distinctive product, diversion is much less likely.

24. For more information about ebola hemorrhagic fever, see The Centers for Disease Control and Prevention, Special Pathogens Branch (2006) available at www.cdc.gov/ncidod/dvrd/spb/mnpages/dispages/ebola.htm.

$25 \quad$ See generally Roger S. Magnusson, Non-Communicable Diseases and Global Health Governance: Enhancing Global Processes to Improve Health Development, 3 Globalization \& HeAlth (May 22, 2007) available at www.globalizationandhealth.com/content/3/1/2.

26 Institute of Medicine, Cancer Control Opportunities in Low- and MiddleIncome Countries (National Academies Press 2007).

27 See generally Thomas A. Gaziano, Reducing The Growing Burden of Cardiovascular Disease in the Developing World, 26 Health AfF. 13 (2007); The Center for Global Health and Economic Development, A Race Against Time: The Challenge of Cardiovascular Disease in Developing Economies (New York: Columbia University, 2004). 
Intellectual Property (the "WHO IGWG"). ${ }^{28}$ The WHO IGWG's task is to distill the WHO CIPIH REPORT into a global strategy and plan of action. This article hopes to influence the final text of the IGWG Global Strategy, finding that disease-specific limitations on access programs and TRIPS flexibilities are inappropriate in markets for medicines, but may have a place in markets for neglected disease innovation.

\section{GLOBAL PHARMACEUTICAL MARKETS FOR MEDICINES \& INNOVATION}

In order to understand the relevance of disease-specific limitations, we must distinguish between markets for medicines and markets for innovation. The patent system joins them together, using patent-protected high prices for medicines to create markets for innovation. James Love and Tim Hubbard have suggested separating these markets through a prize system and generic licensing, ${ }^{29}$ but for the purposes of this article we need only to conceptually distinguish between the two. My aim is to evaluate whether significant differences exist between high-income countries and LMICs that are relevant to global pharmaceutical markets.

\section{A. Markets for Medicines}

IP rights stimulate pharmaceutical innovation by creating an artificial market enforced by patents, trademarks, and exclusivity periods. IP rights enable companies to charge higher prices, which make these medicines more expensive in the absence of generic competition. Patent rents can price most of humanity out of the market, reducing access to life-saving medicines. ${ }^{30}$ Paul Hunt, the UN Special Rapporteur on the right to the highest attainable standard of health, estimates that more than 2 billion people are effectively priced out of the market for patented drugs. ${ }^{31}$ This message has been

28 World Health Organization Intergovernmental Working Group on Public Health, Innovation and Intellectual Property, Draft Global Strategy and Plan of Action on Public Health, Innovation, And Intellectual Property, A/PHI/IGWG/2/2 (July 31, 2007), available at www.who.int/gb/phi/pdf/igwg2/PHI_IGWG2_2-en.pdf [hereinafter WHO IGWG]. An early form of this article was submitted to the WHO IGWG Public Hearing in September, 2007, available at www.who.int/phi/public_hearings/second/co ntributions_section1/Section1_Kevin_Outterson_Boston_Uni_Full_Contribution.pdf.

29 Tim Hubbard \& James Love, A New Trade Framework for Global Healthcare REंD, 2 PLoS Biology 147 (Feb. 2004). Other proposals for separating these markets have been recently summarized in Carl Nathan, Aligning Pharmaceutical Innovation With Medical Need, 13 Nat. Med. 304-308 (2007). The WHO CIPIH Report recommended further investigation of this proposal. WHO CIPIH REPORT, supra note 1, at 178 (Recommendation 3.6). For a philosophical approach, see Thomas Pogge, Harnessing the Power of Pharmaceutical Innovation, in The Power of Pills: Social, Ethical, and Legal Issues in Drug Development, Marketing, and Pricing 142-49 (Jillian Claire Cohen et al. eds., 2006).

$30 \quad$ F.M. Scherer, A Note on Global Welfare in Pharmaceutical Patenting, 27 WoRLD Econ. 1127, 1141 (2004); Pharmaceutical Arbitrage, supra note 4, at 193; Robert Steinbrook, Closing the Affordability Gap for Drugs in Low-Income Countries, 357 NEw ENG. J. MED. 1996-99 (2007).

${ }_{31}$ Paul Hunt, Human Rights Guidelines for Pharmaceutical Companies in Relation to Access to Medicines, 19 Sept. 2007, at 1 (Draft for Consultation), available at www2.essex.ac.uk/human_rights_centre/rth/docs/PH\%20draft\%20guidelines $\% 2019 \% 20$ sept \%202007.doc; see also Oxfam, Oxfam Briefing Paper 109: Investing For Life: Meeting Poor 
articulated for many years by leading advocates for equitable access to medicines. $^{32}$ The WHO CIPIH REPORT found that the effectiveness of IP rights depends greatly on the context, especially the poverty of the patients needing medicines:

But where most consumers of health products are poor, as are the great majority in developing countries, the monopoly costs associated with patents can limit the affordability of patented health-care products required by poor people in the absence of other measures to reduce prices or increase funding. Thus the overall effect of intellectual property regimes is context-specific the impact in a country such as India may differ from that in Thailand or in Ghana. ${ }^{33}$

In wealthier countries, access issues from IP-induced higher prices are ameliorated by government-subsidized insurance and other social mechanisms. The global market for medicines in high-income countries amounts to over $\$ 550$ billion in $2006 .^{34}$ High prescription drug prices are often paid by government or social insurance funds. These payors are the primary global markets for patent-based drug companies, even though some exercise monopsony power to negotiate lower drug prices. ${ }^{35}$ Outside of the

People's Needs for Access to Medicines Through Responsible Business Practices, Nov. 2007, at 2, available at www.oxfam.org/en/files/bp109_investing_for_life_0711.pdf/download.

32 See, e.g., Médecins Sans Frontières, MSF Campaign Brochure 5 (2004), www.msf.org.au/education/resources/access-brochure.pdf ("Medicines aren't just any consumer goods.”); Knowledge Ecology International, IGWG Submission on Collective Management of Intellectual Property - The Use of Patent Pools to Expand Access to Needed Medical Technologies, Sept. 30, 2007, www.who.int/phi/public_hearings/en/; Oxfam, supra note 31 .

33 WHO CIPIH REPORT, supra note 1, at 20.

34. IMS Health estimates the global pharmaceutical market at $\$ 643$ billion in 2006 . Press Release, IMS Health, IMS Health Reports Global Pharmaceutical Market Grew 7.0 Percent in 2006, to $\$ 643$ Billion (Mar. 20, 2007), available at www.imshealth.com/ims/portal /front/articleC/0,2777,6599_3665_80560241,00.html. Companies do not typically break out their financial results by high-income v. low- and medium-income categories, but the World Health Assembly estimated that approximately $90 \%$ of drug sales are in developed countries. Intellectual Property Rights, Innovation, and Public Health, World Health Assembly Res. WHA56.27 10th plen. mtg., (May 28, 2003). My estimates also confirm that $90 \%$ or more of the patent-based drug companies' profits derive from high-income countries. Kevin Outterson, Patent Buy-Outs For Global Disease Innovations For Low- and Middle-Income Countries, 32 Am. J. L. \& Med. 159, 160 (2006). For Merck, approximately 7.5\% of its global revenues come from developing countries. Outterson \& Kesselheim, supra note 8, at 134. In its 2006 Form 10-K filed with the U.S. Securities and Exchange Commission, Merck derived more than half of its global revenue from the United States in 2006. The "other" category accounted for $10.6 \%$ of global revenues, but this category included Australia and New Zealand while excluding Africa and the Middle East. Merck \& Co. Inc., Annual Report (Form 10-K), at 120 n.20 (2007).

35 U.S. Department of Commerce, Pharmaceutical Price Controls in OeCD Countries: Implications For U.S. Consumers, Pricing, Research and Development, AND InNOvation 3 (2004), available at www.ita.doc.gov/td/chemicals/drugpricingstudy.pdf (last visited Mar. 27, 2008) [hereinafter OECD Pricing Report]; see also Kevin Outterson, Testimony Before the Committee on Health, Education, Labor, छ Pensions, United States Senate, Hearing on: Drug Importation: Would the Price Be Right? (Feb. 17, 2005) (critique of the Department of Commerce Report), available at ssrn.com/abstract=706849. 
U.S., public or social insurance funds account for the great majority of OECD pharmaceutical expenditures. ${ }^{36}$

Public subsidies for prescription drug markets are also significant and growing in the U.S. U.S. retail prescription drug expenditures (excluding pharmaceuticals purchased by institutions such as hospitals) topped $\$ 200$ billion in $2005 .{ }^{37}$ Public funds accounted for just $27 \%$ of this U.S. total in 2005 , but that figure will grow substantially with the establishment of Medicare Part D. ${ }^{38}$ This program is projected to cost over $\$ 52$ billion in $2008 .^{39}$ Many purchases of inpatient pharmaceuticals are paid through public funds in Medicare Part A or Medicaid, amounting to tens of billions of dollars per year. Even with these subsidies, drug access problems re-emerge in the U.S. when out-of-pocket costs are high. ${ }^{40}$

Even privately-insured U.S. purchasers receive significant tax subsidies. More than $47 \%$ of U.S. outpatient pharmacy expenditures were covered by private insurance, which itself draws a significant tax subsidy. ${ }^{41}$ The income tax exclusion for employer-provided health insurance is a tax expenditure estimated at $\$ 102.3$ billion in fiscal year $2004 .{ }^{42}$ Since outpatient pharmaceuticals accounted for approximately $10 \%$ of U.S. health spending in $2005,{ }^{43}$ this provision alone is a $\$ 10$ billion tax expenditure supporting the domestic pharmaceutical market.

\section{B. Markets for Pharmaceutical Innovation}

Global expenditures for health research totaled $\$ 125.8$ billion in 2003, from both public and private funds. ${ }^{44}$ Direct expenditures from public funds accounts for about $45 \%$ of the total, approximately $\$ 56.1$ billion in $2003 .^{45}$

36 OECD Pricing Report, supra note 35, at viii-ix.

37 Aaron Catlin et al., National Health Spending In 2005: The Slowdown Continues, 26 Health AfF. 142, 143 exhibit 1 (2007).

38 Centers for Medicare and Medicaid Services, National Health Expenditures By Type of Service and Source of Funds: Calendar Years 2006-1960, available for download at www.cms.hhs.gov/NationalHealthExpendData/02_NationalHealth AccountsHistorical.asp\#TopOfPage (see Prescription Drugs figures at Line 394 in Excel Document) [hereinafter ExPENDITUREs].

39 Congressional Budget Office, The Budget and Economic Outlook: Fiscal Years 2008 to 2017, 58-59 (Jan. 2007) (Box 3-2). The figure cited is the gross cost, which is a more appropriate measure of government subsidy of prescription drug purchases.

${ }_{40}$ Wenke Hwang et al., Out-of-Pocket Medical Spending for Care of Chronic Conditions, 20 Health Aff. 267, 267 (2001); S.B. Soumerai et al., Effects of Medicaid DrugPayment Limits on Admission to Hospitals and Nursing Homes 325 N. Engl. J. Med. 1072 (1991); Bruce Stuart et al., Riding the Rollercoaster: The Ups and Downs In Out-Of-Pocket Spending Under The Standard Medicare Drug Benefit, 24 Health Affairs 1022 (2005); and Tseng Chien-Wen, et al., Elderly Patients' Preferences and Experiences with Providers in Managing Their Drug Costs, 55 J. Am. GER. Soc. 1974, 1974 (2007).

41 EXPENDITURES, supra note 38.

42 U.S. Gov't Accountability Office, GaO-05-690, Expenditures Represent a Substantial Federal Commitment and Need to Be Examined 34 tbl. 2 (2005).

43 Expenditures, supra note 38 . The OECD estimate is higher, at $12.5 \%$ but includes other nondurable medical goods. OECD Health Data: 2007, available at www.oecd.org/document/16/0,3343,en_2825_495642_2085200_1_1_1_1,00.html

(pharmaceuticals and other nondurable medical as a percentage of total health expenditures).

44 Global Forum for Health Research, Monitoring Financial Flows for Health Research 35 (2006).

$45 \quad \mathrm{I} d$. at 39. 
Public funding includes government grants, ${ }^{46}$ such as more than $\$ 28$ billion from the U.S. National Institutes of Health in $2007 .{ }^{47}$ The U.S. is the leading governmental contributor globally. ${ }^{48}$ Government science budgets also contain some health-related funding, which in some countries is quite substantial. ${ }^{49}$ In addition, private non-profit support has been valuable and influential, especially from the Bill \& Melinda Gates Foundation, which has committed $\$ 7.8$ billion to global health through the end of $2006 .^{50}$ The private non-profit sector accounts for approximately $7 \%$ of global health research. ${ }^{51}$

By comparison, the patent-based drug industry trade association reports that global biopharmaceutical R\&D spending was $\$ 55.2$ billion in $2006 . .^{52}$ Similar figures have been criticized as being possibly overstated. ${ }^{53}$ Relying indirectly on the industry-reported numbers, the Global Forum on Health Research estimates the total private for-profit R\&D for health at $\$ 60.6$ billion in $2003 .^{54}$

These estimates of global health $\mathrm{R} \& \mathrm{D}$ understate the true public contribution because they do not include indirect funds such as tax expenditures to support pharmaceutical $R \& D$ and additional periods of marketing exclusivity. ${ }^{55}$ These amounts can be quite significant. In the U.S.,

46 Public Citizen's Congress Watch, Rx R\&D Myths: The Case Against The DRUg INDUSTRY'S R\&D “ScARE CARD” 7 (July 2001) (critiquing the success of pharmaceutical innovation, including a description of the role of public investment); but see ERnst \& Young LlP, Pharmaceutical Industry R\&D Costs: Key Findings about the Public Citizen REPORT (Aug. 8, 2001) (industry-funded response). For a recent proposal concerning publicly funded R\&D, see Ron A. Bouchard, Balancing Public and Private Interests in the Commercialization of Publicly Funded Medical Research: Is There a Role for Compulsory Government Royalty Fees?, 13 B.U. J. ScI. \& TECH. L. 120 (2007) (calling for compulsory government royalties on publicly funded medical research in order to reallocate the benefits and burdens of this public expenditure).

47 NIH Budget 2007, available at www.nih.gov/about/budget.htm.

48 Hamilton Moses III et al., Financial Anatomy of Biomedical Research, 294 J. Am. Med. Ass'N. 1333-42 (2005); European Science Foundation, EMrC White Paper: Present Status and Future Strategy for Medical Research in Europe 16-19 (2007) available

www.esf.org/index.php?eID=tx_ccdamdl_file\&p[file]=14135\&p[dl]=1\&p[pid]=3728\&p[site]

$=$ European $\% 20$ Science $\% 20$ Foundation $\& \mathrm{p}[\mathrm{t}]=1206461812 \&$ hash $=8 \mathrm{~d} 01 \mathrm{cb} 88 \mathrm{ad} 535079299 \mathrm{fd} 6 \mathrm{~d}$ a5fcd9f18\&l=en.

49 OeCD, Science, Technology and Industry Scoreboard 36-7 (2007).

50 Bill \& Melinda Gates Foundation, 2006 Annual Report 14 (2006).

51 Global Forum for Health Research, supra note 44, at 36.

52 Accenture, The Pursuit of High Performance through Research and Development: Understanding Pharmaceutical Research and Development Cost Drivers 4 fig. 2.1.1 (2007).

53 Merrill Goozner, The $\$ 800$ Million Pill: The Truth Behind the Cost of New Drugs (2004); Public Citizen's Congress Watch, supra note 46; but see Ernst \& Young LLP, supra note 46.

54. Global Forum for Health Research, supra note 44, at 39. The Global Forum statistics are derived from the OECD, which itself uses the PhRMA figures for U.S. R\&D. George Messinis, R\&D Price Inflation, Real BERD and Innovation: Pharmaceuticals, OECD 1980-2000 (Working Paper No. 18) (May 2004) available at www.cfses.com/documents/pharma/18-Inflation_Real_BERD_\&_\%20Innovation_Messinis.p df. For estimates of U.S. R\&D spending for health, see Moses III et al., supra note 48, at 1333-42. These figures include only direct expenditures, and exclude tax expenditures.

55 Personal written communication from Hamilton Moses III (Dec. 7, 2007) (on file with author). See Moses III et al., supra note 48. 
the R\&D tax credit, ${ }^{56}$ pediatric testing exclusivity extension, ${ }^{57}$ and the Orphan Drug tax credit ${ }^{58}$ provide subsidies for qualifying research and clinical trial expenses. The U.S. Possessions tax credit provided an additional benefit of $\$ 1.1$ billion in 2003, most of which went to the pharmaceutical industry. ${ }^{59}$ For Merck, the size of its Possessions Tax Credit was dwarfed by the $\$ 1.024$ billion amount saved through tax provisions that permit deferral of foreign income. ${ }^{60}$ Periods of marketing exclusivity are granted under existing U.S. law for clinical trials data, ${ }^{61}$ pediatric testing, ${ }^{62}$ and orphan drugs. ${ }^{63}$ The cost of extending market exclusivity is unclear, but can easily exceed billions of dollars. $^{64}$ The appropriate adjustments for these incentives may be conservatively estimated at no less than $\$ 15$ billion globally, particularly when incentives from outside the U.S. and reimbursement incentives are included. ${ }^{65}$ As adjusted, public investments in health $R \& D$ are probably significantly larger than private for-profit investments (see Table 1).

TABLE 1. ESTIMATED GLOBAL HEALTH R\&D, 2003 (BILLIONS) ${ }^{66}$

\begin{tabular}{|l|l|l|l|}
\hline & Direct & Adjusted & $\%$ \\
\hline Total & 125.8 & 125.8 & \\
\hline Private for-profit & 60.6 & 45.6 & $36 \%$ \\
\hline Private non-profit & 9.0 & 9.0 & $7 \%$ \\
\hline Public & 56.1 & 71.1 & $57 \%$ \\
\hline
\end{tabular}

5626 U.S.C. sec. 41 (2007). The U.S. Treasury estimates the R\&D tax credit was $\$ 4.630$ billion in FY 2004, but did not separately report the portion awarded to the pharmaceutical industry. U.S. Gov'T Accountability OfFice, supra note 42, at 100.

57 Food and Drug Administration Modernization Act of 1997, Pub. L. No. 105-115, 111 STAT. 2296 (codified at 21 U.S.C. $\$ 355 \mathrm{a}$ ).

58 Orphan Drug Act, Pub. L. No. 97-414, 96 Stat. 2049 (1982) (codified as amended as 21 U.S.C. $\$ \S 360 a a-360 e e$ (1994), 26 U.S.C. $\$ 45 C$ (Supp. 11 1994), 42 U.S.C. $§ 236$ (1994)). David Duffield Rohde, The Orphan Drug Act: An Engine of Innovation? At What Cost?, 55 Food \& Drug L.J. 125, 131 (2000). David Loughnot, Potential Interactions of the Orphan Drug Act and Pharmacogenomics: A Flood of Orphan Drugs and Abuses?, 31 Am. J.L. \& Med. 365,365 (2005). The orphan drug tax credit amounts to approximately $\$ 180$ to $\$ 200$ million per year. U.S. Gov't Accountability OfFice, supra note 42, at 105 tbl. 4, app. III.

59 Daniel S. Holik, U.S. Possessions Corporations Returns, 2003, Statistics of Income Bulletin 113, 115 fig. C (2006) (the "pharmaceuticals and medicines" industrial group accounted for $53.1 \%$ ).

6o Merck's Possessions Tax Credit for 2006 was only $\$ 87$ million. Merck \& Co. Inc., Annual Report (Form 10-K), at 114 (Feb. 28, 2007).

$61 \quad$ Federal Food, Drug and Cosmetic Act, 21 U.S.C. $\$ 346 a(i)(1)$ (2007).

$62 \quad$ Food and Drug Administration Modernization Act of $1997 \S 111$.

63 Orphan Drug Act $\$ 527$.

64. Two recent estimates have been made; the lower of the two projected a $\$ 7.7$ billion cost for a single two year "wild card" transferable patent extension. B. Spellberg et al., Societal Costs Versus Savings from Wild-Card Patent Extension Legislation to Spur Critically Needed Antibiotic Development, 35 Infection 167, 167 (2007); Kevin Outterson et al., Will Longer Antimicrobial Patents Improve Global Public Health? 7 LANcet Infectious Diseases 559, 561 (2007).

65 In its comments to the WHO IGWG, the U.S. Government called for additional "tax credits to encourage research and development into medicines related to neglected or orphan diseases.” U.S. Government Comments on Annexes I and II of the World Health Organization (WHO) Secretariat's Elements of a Global Strategy and Plan of Action, at 8, Doc. A /PHI/IGWG/1/5, available at www.who.int/phi/submissions/USA-Comments.pdf [hereinafter, U.S. CoMments].

66 Global Forum for Health Research, supra note 44, at 39 tbl 2.1. 
To a large extent, high-income country governments make the market for pharmaceuticals. Given this fact, separating the public and private contributions to pharmaceutical $R \& D$ becomes exceedingly difficult. But it is clear that direct measures of R\&D greatly understate the public contributions through tax expenditures, regulatory exclusivity, and public reimbursement. The lion's share comes from the public purse.

\section{Implications For LMICs}

The patent-based pharmaceutical R\&D and distribution systems in highincome countries function as well as they do in large part because of elaborate and expensive subsidy and social insurance mechanisms. Poorer countries generally lack these resources. They cannot afford multi-billion dollar NIHstyle grant programs to focus attention on local health conditions. They do not subsidize the cost of the vast array of patented medicines to the point where they are affordable. ${ }^{67}$ Their citizens are much poorer and cannot afford most patented medicines. Global pharmaceutical markets simply do not work as well for the world's non-wealthy people, perhaps $85 \%$ of humanity. ${ }^{68}$ Special provisions for enhanced access to medicines and TRIPS flexibilities are called for in these situations, especially if access can be provided without undermining optimal incentives for innovation in high-income markets. Furthermore, the following section describes why disease-specific limitations are inappropriate.

\section{GLOBAL DISEASE BURDENS}

While pharmaceutical markets vary significantly with the wealth of customers and governments, variations in global disease burdens call for careful analysis. As described above, attempts have been made to limit access initiatives and TRIPS flexibilities to specific diseases or categories, such as the "Big 3" infections diseases (AIDS/HIV, malaria and tuberculosis) or "public health emergencies." Similarly, global drug companies have generally limited their differential pricing policies in LMICs to drugs treating AIDS, malaria and a small number of other drugs. ${ }^{69}$ An implicit assumption is that these conditions represent the greatest disease burdens in LMICs. In fact, these infectious diseases are not the most significant drivers of disease burden in

67 Brazil has fully subsidized the price of AIDS medications as part of its aggressive treatment and prevention program. The high price had prevented Brazil from making similar commitments across other treatment categories. WHO CIPIH REPORT, supra note 1, at 97100 fig. 4.3; Outterson \& Kesselheim, supra note 8, at 133. Brazil's threatened compulsory licenses may have saved US $\$ 1$ billion in AIDS treatment costs between 2001 and 2005. Amy S. Nunn, et al., Evolution of Antiretroviral Drug Costs in Brazil in the Context of Free and Universal Access to AIDS Treatment, 4 PLoS Med. 1804, 1809 (2007).

68 Paul Hunt, supra note 31, at 1; WHO CIPIH REPORT, supra note 1, at 23; see also Oxfam, supra note 31 , at 2 .

69 Oxfam, supra note 31, at 13. 
LMICs, where noncommunicable or chronic diseases play an increasingly significant role. ${ }^{70}$

The Global Forum for Health Research categorizes diseases and disease burdens in LMICs. Their system focuses on medical categories:

Group 1: communicable diseases, maternal and perinatal conditions and nutritional deficiencies

Group 2: noncommunicable conditions (NCDs), including cardiovascular disease, diabetes, cancer and mental and neurological conditions

Group 3: injuries, both intentional and unintentional ${ }^{71}$

In high-income countries, the great majority of burden of disease comes from Group 2; in LMICs, Groups 1 and 2 both account for large shares of the burden of disease. ${ }^{72}$ Historically, some thought of Group 2 diseases, such as heart disease, as diseases of affluence; and Group 1 diseases, such as infant mortality and infections, as diseases of poverty. But the diseases of affluence and poverty are converging. As the Global Forum for Health Research states:

A long-standing stereotype has held that noncommunicable conditions are 'diseases of affluence' characteristic of developed countries, while developing countries mainly suffer from communicable diseases. It is clear that this no longer applies and that a major epidemiological transition has taken place: there is an almost equal level of BoD [Burden of Disease] due to Group 1 and Group 2 for LMICs and a significantly higher rate of DALYs [Disability Adjusted Life Years] in LMICs due to injuries. ${ }^{73}$

The top ten causes of death and burden of disease in LMICs (see Table 2) include several conditions that are also top killers in high-income countries, in addition to more "traditional" diseases of poverty.

TABLE 2. BURDEN OF DISEASE IN LMICS

\begin{tabular}{|l|l|l|l|}
\hline & Death (2001) $^{74}$ & Death (2020 est. $)^{75}$ & $\begin{array}{l}\text { Burden of disease } \\
(\text { 2001, DALY })^{76}\end{array}$ \\
\hline 1. & $\begin{array}{l}\text { Ischaemic heart } \\
\text { disease }\end{array}$ & $\begin{array}{l}\text { Ischaemic heart } \\
\text { disease }\end{array}$ & Perinatal conditions \\
\hline
\end{tabular}

70 See, e.g., Roger S. Magnusson, Non-Communicable Diseases and Global Health Governance: Enhancing Global Processes to Improve Health Development, 3 GLobalization \& HeAlth (May 22, 2007) available at www.globalizationandhealth.com/content/3/1/2.

71 Global Forum for Health Research, 2 Global Forum Update on Research For Health 1, 10-11 (2005); see also Alan Lopez \& Colin Mathers, Inequities in Health Status: Findings From the 2001 Global Burden of Disease Study, 4 Global Forum Update on RESEARCH FOR HEALTH 163, 164 (2007).

72 Global Forum for Health Research, supra note 71, at 11 fig. 3.

73 Id. at 11; for more information on DALY see Disability Adjusted Life Years (DALY), http://www.who.int/healthinfo/boddaly/en/.

74 Lopez \& Mathers, supra note 71, at 169 tbl. 2.

75 Shah Ebrahim \& Liam Smeeth, Non-Communicable Diseases in Low and MiddleIncome Countries: A Priority or a Distraction?, 34 Int'L. J. EPIdemiology 961, 962 tbl. 2 (2005).

$76 \quad$ Lopez \& Mathers, supra note 71 , at $171-72$ tbls. $7 \& 8$. 


\begin{tabular}{|l|l|l|l|}
\hline 2. & $\begin{array}{l}\text { Cerebrovascular } \\
\text { disease }\end{array}$ & $\begin{array}{l}\text { Cerebrovascular } \\
\text { disease }\end{array}$ & $\begin{array}{l}\text { Lower respiratory } \\
\text { infections }\end{array}$ \\
\hline 3. & $\begin{array}{l}\text { Lower respiratory } \\
\text { infection }\end{array}$ & $\begin{array}{l}\text { Chronic obstructive } \\
\text { pulmonary disease }\end{array}$ & Ischaemic heart disease \\
\hline 4. & HIV/AIDS & Tuberculosis & Cerebrovascular disease \\
\hline 5. & Perinatal conditions & Road traffic accidents & HIV/AIDS \\
\hline 6. & $\begin{array}{l}\text { Chronic obstructive } \\
\text { pulmonary disease }\end{array}$ & $\begin{array}{l}\text { Lower respiratory } \\
\text { infections }\end{array}$ & Diarrhoeal diseases \\
\hline 7. & Diarrhoeal diseases & $\begin{array}{l}\text { Trachea, bronchus, } \\
\text { and lung cancers }\end{array}$ & $\begin{array}{l}\text { Unipolar depressive } \\
\text { disorders }\end{array}$ \\
\hline 8. & Tuberculosis & Stomach cancer & Malaria obstructive \\
\hline 9. & Malaria & Diarrhoeal disease & $\begin{array}{l}\text { Chronic } \\
\text { pulmonary disease }\end{array}$ \\
\hline 10. & $\begin{array}{l}\text { Road } \\
\text { accidents }\end{array}$ & HIV/AIDS & \multicolumn{2}{|l}{} \\
\hline & & &
\end{tabular}

Noncommunicable diseases (NCDs) are an increasingly significant problem in the developing world. ${ }^{77}$ As Lopez and Mathers note:

Surprisingly, almost $50 \%$ of the adult disease burden in low- and middle-income countries is now attributable to noncommunicable disease. Population ageing and changes in the distribution of risk factors have accelerated the epidemic of noncommunicable disease in many developing countries. ${ }^{78}$

\section{MARKETS AND THE GLOBAL BURDEN OF DISEASE}

The WHO CIPIH REPORT took a different taxonomic path to describe the global burden of disease, following the terminology of the Commission on Macroeconomics \& Health (CMH) ${ }^{79}$ The CMH and the WHO CIPIH Report categorized diseases with a market-based approach, according to their intrinsic appeal to global capitalism, and in particular with reference to the markets for innovation and medicine.

\section{A. Type I Disease InNovations}

Type I diseases occur in high-income countries. The purchasing power of the high-income countries drives innovation for Type I diseases. Examples

77 See, e.g. the special issue of The LANCET in December 2007 devoted to the burden of chronic diseases, with several articles focusing upon LMICs. Dele O Abegunde et al., The Burden and Costs of Chronic Diseases in Low-Income and Middle-Income Countries, 370 THE LANCET 1929 (2007); Stephen S Lim et al., Prevention of Cardiovascular Disease in High-Risk Individuals in Low-Income and Middle-Income Countries: Health Effects and Costs, 370 THE LAncet 2054 (2007); Robert Beaglehole et al., Prevention of Chronic Diseases: A Call To Action, 370 The LANCET 2152 (2007). For a somewhat contrarian view, see Ebrahim \& Smeeth, supra note 76; but see Kathleen Strong et al., Preventing Chronic Disease: A Priority For Global Health, InT'L. J. Epidemiology 492 (2006) (letter responding to the Ebrahim \& Smeeth article). The WHO CIPIH REPORT strongly noted the growing rate of noncommunicable disease. WHO CIPIH REPORT, supra note 1, at 2-5, 44 .

$78 \quad$ Lopez \& Mathers, supra note 71, at 172.

79 WHO CIPIH REPORT, supra note 1, at 13. 
include cardiovascular disease, stroke, cancer, depression, and diabetes. These diseases may also be prevalent in LMICs, ${ }^{80}$ but the defining characteristic of Type I diseases is a strong market demand for treatment of high-income patients. SARS and pandemic influenza are also Type I disease markets. Innovation in Type I diseases can be sufficiently supported by highincome markets alone.

Some Type I diseases disproportionately affect people in LMICs. Take the example of cervical cancer. The WHO Commission listed cervical cancer as a Type I disease. ${ }^{81}$ In high-income countries, deaths from cervical cancer are relatively rare due to expensive population screening and treatment. About 260,000 women in developing countries die from cervical cancer each year, ${ }^{82}$ exceeding the deaths from all diseases in the tropical-disease cluster. ${ }^{83} \mathrm{~A}$ highly effective vaccine is now available to prevent most cases of cervical cancer, ${ }^{84}$ but the price - US $\$ 360$ per person - exceeds the per capita annual health budgets for most of the women worldwide who need it. ${ }^{85}$ A relatively small number of deaths in high-income countries led to these two HPV vaccines that hold great promise in LMICs as well. These vaccines could be provided generically to the poorest without undermining optimal innovation. The deaths of less than 17,000 women per year in wealthy countries offered sufficient financial rewards to prompt both Merck and GlaxoSmithKline to spend hundreds of millions of dollars to bring HPV vaccines to market. The deaths of more than 222,000 poor women per year may have provided moral, scientific or humanitarian incentives to create HPV vaccines, but the potential financial rewards were modest, since these women cannot afford it. ${ }^{86}$ Merck has announced an equitable access program, ${ }^{87}$ and some limited donations, but the scope of the program remains unknown at the present. ${ }^{88}$

\section{B. Type III Disease InNovations}

Type III diseases are overwhelmingly or exclusively incident in developing countries. Little or no global commercial market exists for Type III diseases. Examples include onchocerciasis (river blindness), leishmaniasis (kala-azar), Chagas disease, and African sleeping sickness.

$80 \quad$ See Bradly Condon \& Tapen Sinha, Global Diseases, Global Patents and Differential Treatment in WTO Law: Criteria for Suspending Patent Obligations in Developing Countries, 26 Nw. J. InT'L L. \& Bus. 1, 25-28 (2005).

81 WHO CIPIH RePorT, supra note 1, at 14 tbl. 1.3.

82 F. Kamangar et al., Patterns of Cancer Incidence, Mortality, and Prevalence Across Five Continents: Defining Priorities to Reduce Cancer Disparities in Different Geographic Regions of the World, 24 J. Clin. Oncology 2137 (2006).

83 C.D. Mathers et al., Global Burden of Disease and Risk Factors 52 tbl. 3.1 (Oxford/World Bank, 2006).

${ }_{84}$ See Diane M. Harper et al., Sustained Efficacy Up To 4.5 Years of a Bivalent L1 Virus-Like Particle Vaccine Against Human Papillomavirus Types 16 and 18: Follow-Up From a Randomised Control Trial, 367 The Lancet 1247 (2006).

85 Outterson \& Kesselheim, supra note 8.

$86 \quad I d$.

87 Press Release, Bill and Melinda Gates Foundation, Cervical Cancer Vaccine Project (Oct. 2006), available at www.path.org/files/RH_cc_vacc_proj_fs_update.pdf.

${ }_{88}$ Press Release, Merck, Merck To Donate Three Million Doses of Gardasil, its Cervical Cancer Vaccine, to Support Vaccination Programs in Lowest Income Nations (Sept. 26, 2007). Three million doses will vaccinate one million women, a very small percentage of the need. 
Many have recognized the market failures inherent in Type III diseases. ${ }^{89}$ For these diseases, normal market conditions will be inadequate to stimulate sufficient R\&D. Impoverished sick people are not attractive markets for global for-profit R\&D programs. ${ }^{90}$ Type III disease innovation will require substantial non-market incentives, such as public-private product development partnerships ${ }^{91}$ and market-making devices such as Advanced Market Commitments ${ }^{92}$ or patent prizes. ${ }^{93}$ Others look to non-market incentives such as grants and government-sponsored research. ${ }^{94}$ Occasionally, proposals are coupled with an expansion of IP rights in poor countries ${ }^{95}$ or a choice between exercising IP rights in either developed or developing countries, but not both. ${ }^{96}$ Expanded IP rights are an unnecessary and unwelcome addition for neglected disease research. Expansion of IP rights will not create incentives in the absence of money to buy the product. These diseases are neglected due to the poverty of the afflicted, not the lack of IP rights. ${ }^{97}$

While Type III diseases are significant, we should note that total global deaths from the tropical-disease cluster in 2001 were only 128,000 people. ${ }^{98}$ Residents of LMICs suffer from higher infectious disease burdens, but much of the DALYs lost stems from noncommunicable diseases, injuries, and communicable diseases other than the tropical and neglected disease cluster. ${ }^{99}$

89 WHO CIPIH REPORT, supra note 1, at 22 ("as is the case for diseases affecting millions of poor people in developing countries, patents are not a relevant factor or effective in stimulating R\&D and bringing new products to market."); see also Carl Nathan, Aligning Pharmaceutical Innovation With Medical Need, 13 NATURE Med. 304 (2007). For a review of the literature, see Pharmaceutical Arbitrage, supra note 4, at 244-50.

90 See, e.g., Médicins Sans Frontiéres, Access to Essential Medicines Campaign \& Drugs for Neglected Diseases Working Group, Fatal Imbalance: The Crisis in Research and Development for Drugs for Neglected Diseases (2001).

91 Mary Moran et al., The New Landscape of Neglected Disease Drug Development (2005), available at www.wellcome.ac.uk.

92 Michael Kremer \& Rachel Glennerster, Strong medicine: Creating INCENTIVES FOR PHARMACEUTICAL RESEARCH ON NEGLECTED DISEASES 119 (Princeton University Press 2004).

93 Aiden Hollis, An Efficient Reward System For Pharmaceutical Innovation 1 (Oct. 6, 2004), available at www.who.int/intellectualproperty/news/en/Submission-Hollis6-Oct.pdf.

94. See Hubbard \& Love, supra note 29; but see Joseph A. DiMasi \& Henry G. Grabowski, Patents and R\&D Incentives: Comments on the Hubbard and Love Trade Framework For Financing Pharmaceutical R\&D 2 (June 25, 2004), available at www.who.int/intellectualproperty/news/en/Submission3.pdf.

95 Alan O. Sykes, TRIPS, Pharmaceuticals, Developing Countries, and the Doha Solution, 3 Chi. J. Int'l. L. 47, 56 (2002); Neglected Diseases: Towards Policies Without Borders, 262 OECD ObSERver (July 2007), available at www.oecdobserver.org/news/fullstory .php/aid/2282/Neglected_diseases.html.

96 Jean O. Lanjouw \& William Jack, Trading Up: How Much Should Poor Countries Pay to Support Pharmaceutical Innovation?, 4 Ctr. For Global Development Brief, Nov. 2004, at 1, available at www.cgdev.org/content/publications/detail/2842/.

97 WHO CIPIH Report, supra note 1, at 22; Pharmaceutical Arbitrage, supra note 4, at $244-50$.

98 Mathers et al., supra note 83, at 52 tbl. 3.1.

99 WHO CIPIH RePORT, supra note 1, at 3-4 tbls. $1.1 \& 1.2$. 


\section{Type II Disease Innovations}

Type II diseases occupy an intermediate category, sharing some characteristics of the other categories. LMICs suffer a disproportionately large burden from Type II diseases. Tuberculosis and malaria were once Type I diseases, but are now classified as Type II by the WHO after virtual eradication of malaria in the U.S. and Europe, and a significantly lower disease burden from tuberculosis in high-income countries. Malaria is classified as Type II rather than Type III because it retains a small but significant financial footprint in the high-income countries to meet the needs of the military and international travelers. If multiple-drug resistant and extremely-drug resistant tuberculosis spread significantly in high-income countries, tuberculosis may regain Type I status.

Innovation in Type II diseases also occupies an intermediate category. In many cases, innovation for high-income markets will be sufficient to create the necessary drugs. Such was the case with AIDS and the existing treatments for malaria and tuberculosis. But the global medical burden of malaria and tuberculosis has outmatched the innovation spurred by relatively modest high-income country markets. Type II diseases will require additional nonmarket incentives to fully correlate global need with innovation incentives. ${ }^{100}$

The WHO Commission classified AIDS as a Type II disease, ${ }^{101}$ but that appears to be a debatable choice. AIDS is perhaps better classified as a Type I disease. While the greatest burden of AIDS disease falls outside of highincome countries, more than 2 million people are living with HIV in highincome countries ${ }^{102}$ and infection rates are rising. ${ }^{103}$ This high-income patient base is more than sufficient to spur innovation. The AIDS cases in the U.S. and Europe sparked an avalanche of research, even before the true scope of the global crisis was known. AIDS may be considered a Type I disease at present, with the exception of adaptive research.

\section{Adaptive Innovations for Type I Diseases}

Additional incentives may be required to adapt Type I innovations to developing country conditions. ${ }^{104}$ Heat-stable formulations ${ }^{105}$ and fixed-dose combinations $^{106}$ are examples of adaptive innovations for a Type I disease (AIDS). Simpler and cheaper diagnostics are required for resourceconstrained settings. Geographic variations in HPV subtype incidence might require additions to the cervical cancer vaccines. ${ }^{107}$ All of these are examples of adaptive innovation for Type I diseases. In the language of the WHO

100 See, e.g., Nathan, supra note 29, at 304-308.

101 WHO CIPIH REPORT, supra note 1 , at 14.

102 UNAIDS, Fact Sheet: Key Facts by Region - 2007 AIDS Epidemic Update (Nov. 2007), data.unaids.org/pub/EPISlides/2007/2007_epiupdate_en.pdf (estimating that 2.1 million people are living with HIV in 2007 in North America, Western and Central Europe).

103 Gardiner Harris, Figures on H.I.V. Rate Expected to Rise, N.Y. Times, Dec. 2, 2007 (reporting that estimates on U.S. infection rates may be $50 \%$ higher than previously thought).

104 WHO CIPIH REPORT, supra note 1, at 16-19, 44.

105 Outterson \& Kesselheim, supra note 8.

106 Pharmaceutical Arbitrage, supra note 4, at 234

107 Nubia Munoz et al., Against Which Human Papillomavirus Types Shall We Vaccinate and Screen? The International Perspective, 111 INT'L. J. CANCER 278, 281-84 (2004). 
Draft Global Strategy (2007), these are "needs of developing countries in relation to Type I diseases."108 Some of this adaptive innovation may come from drug companies located in developing countries, where cost structures are lower and researchers may be closer to the ground. ${ }^{109}$ Other adaptive innovations may require non-market incentives, similar to other neglected disease issues.

\section{E. Important Distinctions Between Markets for Innovation and Medicine}

The WHO typology is helpful for analyzing differences in the markets for innovation and medicine between high-income countries and LMICs. Disease-specific incentives are required for innovation market failures in Type II and III diseases, but limitations are not appropriate for access programs and TRIPS flexibilities. The relevant factors are summarized in Table 3 below:

TABLE 3. MARKETS FOR INNOVATION AND MEDICINES, BY DISEASE TYPE AND INCOME LEVEL.

\begin{tabular}{|l|l|l|}
\hline Type I & Innovation Market & Medicine Market \\
\hline - HICs & $\begin{array}{l}\text { High-income country } \\
\text { purchasing power drives the } \\
\text { market (ex: Lipitor for high } \\
\text { cholesterol). }\end{array}$ & $\begin{array}{l}\text { Patent protection and } \\
\text { sophisticated branding and } \\
\text { marketing yield high drug } \\
\text { prices. }\end{array}$ \\
$\begin{array}{l}\text { Innovation follows purchasing } \\
\text { power rather than medical need } \\
\text { (ex: additional lifestyle and me- } \\
\text { too drugs rather than a first-in- } \\
\text { class Gram-negative antibiotic). } \\
\text { The impact of high prices is } \\
\text { ameliorated by private and } \\
\text { social insurance mechanisms, } \\
\text { relatively high per capita } \\
\text { incomes, and in some cases) } \\
\text { government monopsony } \\
\text { procurement. }\end{array}$ \\
$\begin{array}{l}\text { - LMICs } \\
\text { Adaptive R\&D may be needed } \\
\text { account for resource- } \\
\text { constrained settings (ex. non- } \\
\text { refrigerated vaccines, polyvalent } \\
\text { HPV vaccines, fixed-dose } \\
\text { combinations). }\end{array}$ & $\begin{array}{l}\text { access to the majority of direct } \\
\text { purchasers. Robust generic } \\
\text { competition would drive prices } \\
\text { closer to marginal cost (ex. } \\
\text { unlicensed AIDS drugs) }\end{array}$ \\
$\begin{array}{l}\text { Regional companies may be } \\
\text { able to supply some adaptive } \\
\text { R\&D. The balance must be }\end{array}$ & $\begin{array}{l}\text { LMIC governments and donors } \\
\text { have limited ability to subsidize } \\
\text { access (cf: Thailand \& Brazil's }\end{array}$ \\
\hline
\end{tabular}

108 WhO, Draft Global Strategy and Plan of Action on Public Health, Innovation and Intellectual Property: Progress to Date in Drafting Groups A and B 4-5, A/PI/IGWG/2/Conf.Paper No.1 Rev.1 (Dec. 14, 2007) [hereinafter WHO Draft Global Strategy (2007)].

109 WHO CIPIH REPORT, supra note 1 , at 45. 


\begin{tabular}{|c|c|c|}
\hline & $\begin{array}{l}\text { provided through non-market } \\
\text { incentives. }\end{array}$ & AIDS programs). \\
\hline \multicolumn{3}{|l|}{ Type II } \\
\hline - HICs & $\begin{array}{l}\text { Largely ignored by high-income } \\
\text { markets, except by tourists, } \\
\text { military and other modest } \\
\text { markets (ex: prophylaxis for } \\
\text { malaria). }\end{array}$ & $\begin{array}{l}\text { Patented Type II innovative } \\
\text { medicines are generally limited } \\
\text { to HIC citizens who are } \\
\text { residents in LMICs (ex: military, } \\
\text { tourists, expats, wealthy local } \\
\text { elites). }\end{array}$ \\
\hline -LMICs & $\begin{array}{l}\text { Adequate levels of innovation } \\
\text { require additional R\&D support } \\
\text { from non-market incentives } \\
\text { (ex: malaria vaccine) }\end{array}$ & $\begin{array}{l}\text { LMIC governments and donors } \\
\text { have limited ability to subsidize } \\
\text { access. Best medical practice } \\
\text { may require significant subsidies } \\
\text { to prevent resistance to } \\
\text { communicable diseases (ex: } \\
\text { subsidies for ACTs for malaria). }\end{array}$ \\
\hline \multicolumn{3}{|l|}{ Type III } \\
\hline & No r & No \\
\hline - LMICs & $\begin{array}{l}\text { These very neglected diseases } \\
\text { require non-market incentives } \\
\text { to support innovation. }\end{array}$ & $\begin{array}{l}\text { Significant unmet medical need } \\
\text { in LMICs. }\end{array}$ \\
\hline
\end{tabular}

\section{DISEASE-SPECIFIC LIMITATIONS IN THE WHO IGWG}

With this background, we now turn to the current discussions within the WHO IGWG concerning disease-specific limitations. The December 14, 2007 draft of the WHO Draft Global Strategy $(2007)^{110}$ frequently uses the following disease-limiting phrase or its permutations: "diseases which disproportionately affect developing countries."111 The phrase was prominently discussed in the WHO CIPIH RePorT, ${ }^{112}$ and was mentioned in the World Health Assembly Resolution that established the IGWG. ${ }^{113}$ The phrase is occasionally used as an apparent synonym for Type II and III diseases.

\section{A. The U.S. Position}

The United States Government appears to consider the phrase as a limitation on access programs. In the U.S. Comments to the WHO Elements of a Global Strategy (2006), the United States claimed that the IGWG's mandate was limited to Type II and III diseases:

110 WHO Draft Global Strategy (2007). An earlier draft is WHO, Elements of a Global Strategy and Plan of Action, A/PHI/IGWG/1/5 (Dec. 8, 2006) [hereinafter WHO Elements of a Global Strategy (2006)].

111 WHO Draft Global Strategy (2007), at 3-5 ๆ 9 3, 4, 13, 14(a), 14(b).

112 WHO CIPIH REPORT, supra note 1.

113 World Health Assembly [WHA] Res. 59.24 (May 27, 2006). 
The IGWG should not consider Recommendation 2.4 as the focus of its work should be on diseases that disproportionately affect developing countries, more commonly referred to as Type II and Type III diseases. ${ }^{114}$

The United States was commenting on Recommendation 2.4 from the WHO CIPIH Report, which explicitly included Type I diseases in its ambit:

When addressing the health needs of people in developing countries, it is important to seek innovative ways of combating Type I diseases, as well as Type II and Type III diseases. Governments and funders need to assign higher priority to combating the rapidly growing impact of Type I diseases in developing countries, and, through innovation, to finding affordable and technologically appropriate means for their diagnosis, prevention and treatment. ${ }^{115}$

Other actions by the U.S. Government have attempted to limit IGWG consideration of TRIPs flexibilities, especially with regard to Type I diseases. For example, the WHO CIPIH REPORT ${ }^{116}$ and the World Health Assembly Resolution $59.24^{117}$ supported the use of TRIPS flexibilities by developing countries. The WhO Elements of a Global Strategy (2006) included the following "areas for action:"

6(a) enact legislation in developed and developing countries for application of the flexibilities provided for in TRIPS and other international agreements

6(f) assure that bilateral trade agreements do not seek to incorporate "TRIPS-plus" protection in ways that might reduce access to medicines in developing countries

6(i) focus on specific aspects of the intellectual property system, such as test data exclusivity, 'me-too' patents, and patent linkages

7(i) take necessary legislative steps in developed countries, and other countries with manufacturing and export capacity, to allow compulsory licensing for export consistent with the flexibilities provided for in TRIPS

$7(\mathrm{j})$ provide in national legislation for measures to encourage generic entry on patent expiry, such as the 'early working' exception, and more generally policies that support greater competition between generics, whether branded or not, as an effective way to enhance access by improving affordability; restrictions should not be placed on the use of generic names ${ }^{118}$

U.S. Comments, supra note 65, at 2.

WHO CIPIH REPORT, supra note 1, at 48 (Recommendation 2.4).

Id. at 22 .

WHA Res. 59.24, supra note 113 , at $\S 2$ ฯ 4 .

WHO Elements of a Global Strategy (2006), supra note 110, at 6-8. 
The U.S. Comments requested that these discussions of TRIPS flexibilities be excluded from the WHO IGWG process: ${ }^{119}$

Accordingly, the IGWG should not consider Subsection (a) of Paragraph Six of the document. The WHO Secretariat should not expand its work on matters better addressed by another international organization. Therefore, the IGWG should not consider Subsections (f) and (i) of Paragraph Six of the document, because they more appropriately fit within the scope and mandate of the WTO and WIPO. ${ }^{120}$

While Subparagraph (j) of Paragraph Seven is important when balanced with incentives to develop new drugs, neither subparagraph (i) or ( $j$ ) are appropriate areas of action for the WHO Secretariat; thus the IGWG should not consider them. ${ }^{121}$

The U.S. Comments are thus making a narrow, technocratic argument that the WHO is an inappropriate forum for discussing the intellectual property rights issues relating to access to medicines. They are trying to prevent discussion in a forum that might actually give some weight to global health. This argument ignores the history of the IGWG process, which was designed to offer a balanced, integrated analysis of intellectual property rights, innovation and public health. Each step of this process has highlighted all three issues: The WHO Commission on Intellectual Property Rights, Innovation and Public Health; the WHO CIPIH Report entitled Public Health, Innovation \& Intellectual Property Rights; and the WHO igWG on Public Health, Innovation and Intellectual Property. The WHO is not claiming exclusive jurisdiction over these issues, but merely the opportunity to speak to issues which impact global public health.

\section{B. Disease-Specific Limitations Are Not Appropriate}

Nothing in the TRIPs Agreement or the Doha Declaration limits access programs or TRIPS flexibilities to Type II and III diseases. Neither does the WHO CIPIH REPORT, which cannot be read as arguing for any such restriction.

The phrase "diseases which disproportionately affect developing countries" is best understood as an explanation for why the market has failed to produce medicines for neglected (Type II) or very neglected (Type III) diseases: diseases which disproportionately affect poor people in LMICs are not an attractive market for the patent-based drug industry. As the WHO CIPIH REPORT concluded:

119 U.S. Comments, supra note 65, at 4-6, ๆ 7 7-8. The U.S. Comments suggest that the WTO and WIPO are the better fora.

$120 \quad$ Id. at 5 ฯ 6.

$121 \quad I d$. at 5 ฯ 7 . 
Too few R\&D resources are directed to the health needs of developing countries. In the private sector, companies do not have the incentive to devote adequate resources to develop products specifically adapted to the needs of developing countries, because profitability is mainly to be found in rich country markets. The great majority of health research funded by the public sector, takes place in developed countries, and its priorities principally reflect their own disease burden, resource position and social and economic circumstances. ${ }^{122}$

Difficulties with the U.S. position are made more evident when one attempts to construct a list of qualifying diseases. The adverb "disproportionately" appears to require that incidence on a per capita basis be significantly higher. Surely the list includes all Type III diseases, including the very neglected tropical diseases, for by definition the per capita incidence is almost exclusively in LMICs. Similarly, the largest Type II diseases such as malaria and tuberculosis appear to qualify. For all of these diseases, markets are unable to stimulate the $\mathrm{R} \& \mathrm{D}$ required for global health.

AIDS presents a more troublesome case. The incidence and burden of AIDS falls disproportionately on sub-Saharan Africa, but the same may not hold true for India or China. As discussed above, AIDS may not be properly classified as a Type II disease at all, and its incidence is rising in the United States. ${ }^{123}$

Other infectious diseases are quite common in LMICs, and result in a substantial burden of disease there. In general, the incidence of infectious diseases falls disproportionately in LMICs, but significant medical need exists also in high-income countries for many infectious diseases. ${ }^{124}$

Most noncommunicable or chronic diseases would probably not qualify. While heart disease, depression, stroke, and diabetes are certainly major contributors to the burden of disease in LMICs, they do not impose a disproportionately higher per capita burden. If the phrase "diseases which disproportionately affect developing countries" is considered a limitation on access programs and TRIPS flexibilities, then almost all chronic and noncommunicable diseases must be excluded.

Clearly, this is not an acceptable result. This interpretation is without support in the WHO CIPIH REPORT, and is at odds with the mandate of the WHO IGWG. The Report does not limit access programs or TRIPs flexibilities to specific diseases. In fact, it recommended exactly the opposite. Recommendations 4.13 to 4.27 are primarily concerned with encouraging developing countries to take advantage of TRIPS flexibilities and other laws in order to protect public health, without any limitations as to disease. ${ }^{125}$ Recommendation 4.7 specifically includes noncommunicable diseases:

122 WHO CIPIH REPORT, supra note 1, at 172.

123 See infra Part IV.C.

124 See, e.g., Elli Klein et al., Hospitalizations and Deaths Caused By MethicillinResistant Staphylococcus aureus, United States, 1999-2005, 13 Emerging Infectious Diseases 1840 (2007); R. Monina Klevens et al., Invasive Methicillin-Resistant Staphylococcus aureus Infections in the United States, 298 J. Am. Med. Ass'N. 1763 (2007).

${ }_{125}$ WHO CIPIH REPORT, supra note 1, at 180-82. 
4.7 For noncommunicable diseases, governments and companies should consider how treatments, which are widely available in developed countries, can be made more accessible for patients in developing countries. ${ }^{126}$

The phrase "diseases which disproportionately affect developing countries" is relevant only as a descriptive term, identifying innovation market failures: patent-based pharmaceutical innovation does not work for diseases which disproportionately affect developing countries. Global markets underproduce commercial research on Type II diseases, Type III diseases, and adaptive research for Type I innovations for resource-constrained settings. No substantial market in high-income countries exists for these disease conditions, necessitating various non-market mechanisms in order to facilitate innovation. By definition, these conditions disproportionately affect developing countries; otherwise they would be Type I innovations.

Yet the innovation gap is not the only problem facing the IGWG. Its terms of reference also include ensuring equitable access to patented innovations treating all diseases, including Type I, II and III diseases. The market for medicines and the market for innovation must both be valued. WHA 59.24 urges member states:

to work to ensure that progress in basic science and biomedicine is translated into improved, safe and affordable health products drugs, vaccines and diagnostics - to respond to all patients' and clients' needs, especially those living in poverty, taking into account the critical role of gender, and to ensure that capacity is strengthened to support rapid delivery of essential medicines to people. ${ }^{127}$

\section{CONCLUSION}

The pharmaceutical IP system works to some degree in high-income countries with generous government subsidies and social insurance. It does not work well for the poor in low- and middle-income countries. For the market for medicines, governments should fully utilize all TRIPS flexibilities to protect the health of their citizens, without regard to the type of disease. In particular, LMICs must be permitted to confront the growing burden of chronic diseases by using TRIPS flexibilities for any type of disease, including Type I. The phrase "diseases disproportionately affecting developing countries" is in no way a limitation on the utilization of TRIPS flexibilities to improve the market for medicines in WTO Member countries. Rather, it is an important reminder of a weakness in the market for innovation; global commercial markets will not invest sufficient amounts in diseases that disproportionately affect developing countries.

\footnotetext{
$126 \quad$ Id. at 180.

127 WHA Res. 59.24, supra note 113 , at $\$ 2$ ๆ 3.
} 